\title{
Nitrogen Recovery from Clear-Cut Forest Runoff Using Biochar: Adsorption-Desorption Dynamics Affected by Water Nitrogen Concentration
}

\author{
E. Kakaei Lafdani (D) Ari Laurén • \\ Jovana Cvetkovic $\cdot$ Jukka Pumpanen • \\ Taija Saarela $\cdot$ Marjo Palviainen
}

Received: 7 May 2021 / Accepted: 24 September 2021 / Published online: 12 October 2021

(C) The Author(s) 2021

\begin{abstract}
Forest regeneration operations increase the concentration of nitrogen $(\mathrm{N})$ in watercourses especially outside the growing season when traditional biological water protection methods are inefficient. Biochar adsorption-based water treatment could be a solution for nutrient retention. We studied the total nitrogen (TN) and nitrate-nitrogen $\left(\mathrm{NO}_{3}{ }^{-} \mathrm{N}\right)$ adsorption-desorption properties of spruce and birch biochar. The adsorption test was performed under four different initial concentrations of $\mathrm{TN}(1,2,3$, and $4 \mathrm{mg} \mathrm{L}^{-1}$ ) using forest runoff water collected from ditch drains of boreal harvested peatland. The results showed that the TN adsorption amount increased linearly from the lowest to the highest concentration. The maximum adsorption capacity was 2.4 and 3.2
\end{abstract}

Supplementary Information The online version contains supplementary material available at https://doi. org/10.1007/s11270-021-05366-y.

E. Kakaei Lafdani $(\bowtie) \cdot$ A. Laurén · J. Cvetkovic

School of Forest Sciences, University of Eastern Finland, Yliopistokatu 7, FI-80101 Joensuu, Finland

e-mail: elhka@uef.fi

A. Laurén

e-mail: ari.lauren@uef.fi

J. Cvetkovic

e-mail: cvetkovicjovana94@gmail.com

J. Cvetkovic

Department of Ecological Engineering for Soil and Water Resources Protection, Faculty of Forestry, University of Belgrade, 11030 Belgrade, Serbia times greater in the highest concentration $\left(4 \mathrm{mg} \mathrm{L}^{-1}\right)$ compared to the lowest concentration $\left(1 \mathrm{mg} \mathrm{L}^{-1}\right)$ in spruce and birch biochar, respectively. The $\mathrm{NO}_{3}{ }^{-}-\mathrm{N}$ adsorption amount of birch biochar increased linearly from 0 to $0.15 \mathrm{mg} \mathrm{NO}_{3}{ }^{-}-\mathrm{N} \mathrm{g}_{\text {biochar }}{ }^{-1}$ when the initial concentration of $\mathrm{NO}_{3}{ }^{-}-\mathrm{N}$ increased from 0.2 to $1.4 \mathrm{mg} \mathrm{L}^{-1}$. However, in spruce biochar, the initial concentration did not affect $\mathrm{NO}_{3}{ }^{-}-\mathrm{N}$ adsorption amount. The results indicate that concentration significantly affects the biochar's capacity to adsorb $\mathrm{N}$ from water. The desorption test was performed by adding biochar extracted from the adsorption test into the forest runoff water with low $\mathrm{TN}$ concentration $(0.2$ or $\left.0.35 \mathrm{mg} \mathrm{L}^{-1}\right)$. The desorption results showed that desorption was negligibly small, and it was dependent on the TN concentration for birch biochar. Therefore, biochar can be a complementary method supporting water purification in peatland areas.

\footnotetext{
J. Pumpanen · T. Saarela

Department of Environmental \& Biological Sciences, University of Eastern Finland, Yliopistonranta $1 \mathrm{E}$, FI-70210, Kuopio, Finland e-mail: jukka.pumpanen@uef.fi

T. Saarela

e-mail: taija.saarela@uef.fi

M. Palviainen

Department of Forest Sciences, University of Helsinki, Latokartanonkaari 7, FI-00014 Helsinki, Finland e-mail: marjo.palviainen@helsinki.fi
} 
Keywords Adsorption-desorption capacity · Forest regeneration · Nutrient retention · Peatland - Water protection

\section{Introduction}

Leaching of $\mathrm{N}$ from drained peatland forests is remarkably higher (Nieminen et al., 2017) than from upland forests (Finér et al., 2021), and especially forest regeneration in peatlands imposes a threat to the quality of surface waters (Nieminen et al., 2005). Hytönen et al. (2020) estimated that 700,000 ha of peatland forests will reach regeneration age within the following 10 years in Finland, which is an increasing challenge for water protection. Large varieties of different water protection methods, such as sedimentation pits, sedimentation ponds, and peatland buffer areas, have been used to mitigate the nutrient export load to watercourses (Kalvīte et al., 2019; Marttila \& Kløve, 2010), but all these are rather ineffective in reducing dissolved nutrient export loads particularly outside the growing season (Joensuu et al., 2002; Liljaniemi et al., 2003; Nieminen et al., 2005). Therefore, additional water purification methods are needed. Methods based on adsorption can be suitable for this purpose, as they are capable of eliminating both organic and inorganic pollutants from water also outside the growing season (Battas et al., 2019). Adsorption-based water purification methods have been shown to be effective in the treatment of municipal wastewaters and urban and agricultural runoff (Singh et al., 2018).

Biochar has been shown to be an effective adsorbent (Laird et al., 2010; Jin et al., 2016; Wang et al., 2015; Liu et al., 2020; Saarela et al., 2020). Biochar is formed when organic material is heated under limited oxygen concentration in the pyrolysis process. Biochar is stable, highly aromatic, and carbon-rich material (Beesley et al., 2011; Gaunt \& Lehmann, 2008), and its adsorption capacity is based on high porosity, large specific surface area (Accardi-Dey \& Gschwend, 2003; Kookana, 2010), and surface charges (Li et al., 2015; Liu et al., 2020; Mohan et al., 2014). The adsorption capacity of biochar varies with the properties of the raw materials, the pyrolysis temperature, and other manufacturing parameters (Liu et al., 2020).
Adsorption-based water protection has several challenges. A characteristic feature of nutrient export from forest areas is high water volume and concentration that is rather low compared to that in wastewater or in agricultural and urban runoff waters (Oliveira et al., 2018), and the nutrient concentration fluctuates seasonally (Mattsson et al., 2015). Therefore, the adsorbent must recover nutrients from a rather low concentration, high water volume, and in the presence of high dissolved organic matter concentration and should persist the adsorption under fluctuating nutrient concentrations. It has been reported that the adsorption amount increases with increasing element concentration in water (Ahmadvand et al., 2018; Saarela et al., 2020). This implies that the adsorption amount is improved when the runoff nutrient concentrations increase in the seasonal cycle. However, less attention has been paid to investigate the effect of decreasing concentration on the possible desorption of $\mathrm{N}$ compounds. Desorption occurs when adsorbed nutrients are released from the surface of biochar. Knowing the desorption of the recovered $\mathrm{N}$ is crucially important when biochar is applied as a water protection tool. Only a few studies before have examined the utility of biochar in peatland forest areas (Kakaei Lafdani et al., 2020; Saarela et al., 2020), and according to our knowledge, this is the first study to address the $\mathrm{N}$ adsorption-desorption processes in peatland runoff water. The current experiment was conducted to examine the effect of $\mathrm{N}$ concentration on the adsorption-desorption behavior of spruce and birch biochars in the water collected from a ditch draining a clear-cut peatland forest area. The main objectives are as follows:

1. To investigate the effect of $\mathrm{TN}$ concentrations in water on the adsorption amount

2. To determine adsorption kinetics under different $\mathrm{TN}$ concentrations in water

3. To quantify the desorption amount of recovered $\mathrm{TN}$ in birch and spruce biochar

\section{Materials and Methods}

\subsection{Study Site and Water Collection}

The study site is located in Heinävesi, in Eastern Finland $\left(62^{\circ} 29^{\prime} 56.0^{\prime \prime} \mathrm{N}, 28^{\circ} 35^{\prime} 56.0^{\prime \prime} \mathrm{E}\right)$. The mean annual 
temperature and precipitation in the area are $3.6{ }^{\circ} \mathrm{C}$ and $638 \mathrm{~mm}$, respectively. The site was a drained fertile spruce fen that was clear-cut in August 2018. In the clear-cut, a total of $319 \mathrm{~m}^{3}\left(124 \mathrm{~m}^{3} \mathrm{ha}^{-1}\right)$ Norway spruce (Picea abies Karst.) and $239 \mathrm{~m}^{3}\left(93 \mathrm{~m}^{3} \mathrm{ha}^{-1}\right)$ silver birch (Betula pendula Roth.) were harvested. The total catchment area was 31.72 ha, and the area of 2.57 ha was clear-cut. The depth of the peat layer was $0.5-0.7 \mathrm{~m}$, and it was underlain by clay.

Water for the adsorption and desorption laboratory experiments was collected from a ditch that drains the clear-cut area. The water was collected outside the growing season (November 2019) when the TN concentration was $4.6 \mathrm{mg} \mathrm{L}^{-1}$. Water was stored at $+4{ }^{\circ} \mathrm{C}$ before the experiments.

\subsection{Biochar Properties}

We used commercial biochar (Carbofex Ltd, Tampere, Finland) manufactured from Norway spruce (Picea abies L. Karst.) and silver birch (Betula pendula Roth) wood chips. The characteristics of biochars are shown in Table 1. Electrical conductivity (EC) and $\mathrm{pH}$ of biochars (on a 1:2.5 v:v biochar/water solution) were measured using WTW pH/cond 340i and WTW pH 340 sensors (WTW GmbH, Weilheim, Germany), respectively. $\mathrm{N}$ concentrations of biochars were analyzed with an elemental analyzer (Vario Max CN elemental analyzer, Elementar Analysensysteme $\mathrm{GmbH}$, Germany). The specific surface area was measured using the $\mathrm{N}_{2}$ adsorption method (Micromeritics Flowsorb II 2300, 1986).

Table 1 Characteristics of the spruce and birch biochars. Values are mean $( \pm \mathrm{SD})$

\begin{tabular}{lll}
\hline & Spruce & Birch \\
\hline Particle size $(\mathrm{mm})$ & $4-6$ & $4-6$ \\
Pyrolysis temperature $\left({ }^{\circ} \mathrm{C}\right)$ & $600{ }^{\circ} \mathrm{C}$ & $600{ }^{\circ} \mathrm{C}$ \\
Electric conductivity $\left(\mu \mathrm{S} \mathrm{cm}^{-1}\right)$ & $221(15)$ & $163(3)$ \\
$\quad(1: 2.5 \mathrm{v}: \mathrm{v}$ biochar/water solu- & & \\
$\quad$ tion $)$ & & \\
$\mathrm{pH}(1: 2.5$ v:v biochar/water & $9.25(0.01)$ & $9.75(0.02)$ \\
$\quad$ solution $)$ & & \\
Specific surface area $\left(\mathrm{m}^{2} \mathrm{~g}^{-1}\right)$ & 320 & 260 \\
$\mathrm{~N} \%$ & $1.19(0.09)$ & $1.39(0.15)$ \\
$\mathrm{C} \%$ & $79.07(0.83)$ & $80.00(0.05)$ \\
$\mathrm{C}: \mathrm{N}$ ratio & $66.9(5.51)$ & $58.2(6.38)$ \\
Dry matter $(\%)\left(105{ }^{\circ} \mathrm{C}, 48 \mathrm{~h}\right)$ & $72.6 \%(2.74)$ & $81.0 \%(1.86)$ \\
\hline
\end{tabular}

\subsection{Adsorption Experiment}

To study the effect of $\mathrm{N}$ concentrations on the adsorption, runoff water was diluted to concentrations of 1, 2, 3, and $4 \mathrm{mg} \mathrm{L}^{-1} \mathrm{TN}$ by adding Milli-Q water (Appendix, Fig. 7). Before the experiment, the water temperature was allowed to stabilize to $+21{ }^{\circ} \mathrm{C}$. Five grams (dry mass) of spruce or birch biochar was added to $1 \mathrm{~L}$ of runoff water. Each concentration contained three biochar replicates and one blank control without biochar. The jars were covered with aluminum foil and placed on a platform shaker (New Brunswick ${ }^{\mathrm{TM}}$ Innova ${ }^{\circledR}$ 2300, Eppendorf Nordic A/S, Denmark). Glass jars were shaken at $110 \mathrm{rpm}$ for 10 days, and $30 \mathrm{~mL}$ water sample was taken from each jar at the following points of time: $0,2,5,25,48,72,125$, and $173 \mathrm{~h}$ from the beginning of the experiment. The water samples were filtered through a filtration assembly with Whatman GF/F glass microfiber filters (pore size $0.45 \mu \mathrm{m}$, GE Healthcare Bio-Sciences, Marlborough, MA, USA) and stored at $+4{ }^{\circ} \mathrm{C}$ until further analysis.

TN concentrations were determined with multi N/ C® 2100 (Analytik Jena AG, Jena, Germany). The concentrations of $\mathrm{NO}_{3}{ }^{-}-\mathrm{N}$ and $\mathrm{NH}_{4}{ }^{+}-\mathrm{N}$ were determined colorimetrically applying the methods by Miranda et al. (2001) and Fawcett and Scott (1960), respectively.

$\mathrm{N}$ adsorption amount $\left(Q_{t}\right)$ to biochar was computed from the observed concentration change in the water (Eq. 1):

$A_{t p}=\frac{\left(c_{\text {ini } p} v_{\text {ini }}\right)-\sum_{t=\text { ini }}^{n}\left(c_{t-1 p}-c_{t p}\right) v_{t-1, t}}{m_{\text {biochar }}}$

where $A_{t p}$ is the cumulative adsorption amount of substance $p\left(p=\mathrm{TN}, \mathrm{NO}_{3}{ }^{-}-\mathrm{N}, \mathrm{NH}_{4}{ }^{+}-\mathrm{N}\right)$ in $\mathrm{mg}\left(\mathrm{g}^{-1}\right.$ biochar), $c_{\text {ini } p}$ is the initial concentration of substance $p\left(\mathrm{mg} \mathrm{L}^{-1}\right), v_{\text {ini }}$ is the water initial volume $(\mathrm{L}), c_{t} p$ is the concentration of substance $p$ in time $t\left(\mathrm{mg} \mathrm{L}^{-1}\right)$, $c_{t-1 p}$ is the concentration of substance $p$ in time $t-1$ $\left(\mathrm{mg} \mathrm{L}^{-1}\right), v_{t-1, t}$ is water volume at a time interval from $t-1$ to $t(\mathrm{~L})$, and $m_{\text {biochar }}$ is the dry mass of biochar in the jars.

The effect of the initial TN concentration on the TN adsorption for birch and spruce biochar was studied using the cumulative adsorption amount of $\mathrm{TN}$ at the end of the experiment $\left(A_{173 \mathrm{~h}}\right)$ using linear mixedeffect models. Biochar type was used as fixed effects, replicates were considered random effects, and the 
independent variable was the initial concentration. The model was formulated as follows:

$A_{173, p i}=\alpha_{p, i}+\beta_{p, i} C_{\mathrm{ini}, p, i}+\varepsilon_{p, i j}$

where $A_{173, p i}$ represents the adsorption amount of substance $p\left(\mathrm{TN}, \mathrm{NO}_{3}{ }^{-}-\mathrm{N}\right)$ to the biochar $i(\mathrm{Bb}, \mathrm{Sb}$, unit $\mathrm{mg} \mathrm{g}^{-1}$ biochar) at time $173(\mathrm{~h}), \alpha_{p, i}$ and $\beta_{p, i}$ are fixed parameters for substance $p$ and biochar $i, C_{\text {ini, } p}$ is the initial concentration $\left(\mathrm{mg} \mathrm{L}^{-1}\right)$ for substance $p$. $\varepsilon_{p i j}$ is a residual term for substance $p$ and biochar $i$ and replicant $j$ with the expectation value of 0 . The performance of the model was expressed as information criteria (AIC, BIC, -log likelihood, RMSE, and $R^{2}$ ).

Adsorption kinetics (adsorption rate and maximum adsorption capacity) were determined by fitting a commonly used integral form of pseudo-first order (Eq. 3) and pseudo-second order (Eq. 4) adsorption models (Largitte \& Pasquier, 2016) to the data.

$A_{p}=Q_{\max , p}\left(1-e^{-k_{a d l p} \cdot t}\right)$

$A_{p}=\left(\frac{k_{\mathrm{ad} 2 \_p}{ }^{2} Q_{\max \_p} t}{1+k_{\mathrm{ad} 2 \_p} Q_{\max \_p} t}\right)$

where $A_{p}$ is the cumulative adsorption of substance $p$ (TN, and $\mathrm{NO}_{3}{ }^{-}-\mathrm{N} \mathrm{mg} \mathrm{g}{ }^{-1}$ biochar) at time $t(\mathrm{~h}$ ). $k_{\text {ad1,p }}$ is the adsorption rate in pseudo-first order model $\left(\mathrm{h}^{-1}\right)$ and $k_{\mathrm{ad} 2, p}$ in pseudo-second order model $\left(\mathrm{mg} \mathrm{g}^{-1} \mathrm{~h}^{-1}\right) . Q_{\max 1, p}$ and $Q_{\max 1, p}$ are the maximum adsorption capacity at equilibrium ( $\mathrm{mg} \mathrm{g}^{-1}$ biochar) for substance $p$.

\subsection{Desorption Experiment}

We studied the desorption of TN in a two-stage experiment consisting of adsorption and desorption phases (Appendix, Fig. 8). In the adsorption phase, we stirred $5 \mathrm{~g}$ of birch and spruce biochar with $1 \mathrm{~L}$ of runoff water in four different $\mathrm{TN}$ concentrations and three replicates. The runoff water with the original TN concentration of $4.6 \mathrm{mg} \mathrm{L}^{-1}$ was diluted with Milli-Q water to approximate concentrations of $1 \mathrm{mg} \mathrm{L}^{-1}, 2 \mathrm{mg}$ $\mathrm{L}^{-1}, 3 \mathrm{mg} \mathrm{L}^{-1}$, and $4 \mathrm{mg} \mathrm{L}^{-1}$ of TN. The duration of the adsorption phase was $72 \mathrm{~h}$. At the beginning and at the end of the adsorption phase, the TN concentration of water was determined, and the amount of adsorbed $\mathrm{TN}\left(A_{\mathrm{TN}}\right)$ to the biochar was calculated using Eq. 1. The biochar was filtered and divided into two samples with a mass of $2.5 \mathrm{~g}$. For the desorption phase, the biochar samples were placed into glass bottles and stirred with the runoff water diluted to $0.2 \mathrm{mg} \mathrm{L}^{-1}$ and $0.35 \mathrm{mg} \mathrm{L}^{-1}$ using Milli-Q water in 250-mL total volume. The bottles were shaken at $110 \mathrm{rpm}$ for 9 days; after which, water samples were taken and the TN concentration was analyzed. The desorption amount was calculated as follows:

$D_{c i}=\frac{\left(c_{\text {end }-} c_{\text {ini }}\right) v}{m_{\text {biochar }}}$

where $D_{c i}$ is TN desorption amount for biochar $i(\mathrm{Bb}, \mathrm{Sb})$ in concentration $c\left(0.20\right.$ and $\left.0.35 \mathrm{mg} \mathrm{L}^{-1}\right), c_{\text {end }}$ is solution $\mathrm{TN}$ concentration at the end of desorption phase (mg $\left.\mathrm{L}^{-1}\right), c_{\text {ini }}$ is the solution TN concentration at the beginning of the desorption phase $\left(\mathrm{mg} \mathrm{L}^{-1}\right), v$ is the solution volume (L), and $m_{\text {biochar }}$ is the biochar mass in the bottle.

The effect of the initial TN concentration on the TN desorption amount for birch and spruce biochar was examined by the cumulative desorption amount of $\mathrm{TN}$ at the end of the experiment $\left(D_{216 \mathrm{~h}}\right)$ using linear mixed-effects models (Eq. 6). Biochar type, replicates, and the initial concentration were considered fixed effects, random effects, and the independent variable, respectively, as follows:

$D_{216, i}=\alpha+\alpha_{S}+\left(\beta+\beta_{S}\right) X_{\mathrm{ini}, i}+\varepsilon_{, i j}$

where $D_{216, i}$, represents the desorption amount of TN to the biochar $i\left(\mathrm{mg} \mathrm{g}^{-1}\right.$ biochar) at time $216(\mathrm{~h}), \alpha$ and $\beta$ are fixed parameters for birch biochar, $\alpha_{S}$ and $\beta_{S}$ are fixed parameters for spruce biochar expressed as the difference from the birch fixed parameters, and $X_{\text {ini }}$ is the initial concentration $\left(0.2\right.$ and $\left.0.35 \mathrm{mg} \mathrm{L}^{-1}\right)$ for TN. In the case of birch biochar, $\alpha_{S}$ and $\beta_{S}$ are zero. The amount of adsorbed TN at the end of the adsorption phase of the desorption experiment $(\mathrm{mg}$ $\mathrm{g}^{-1}$ biochar), and $\varepsilon_{i j}$ is a residual term for TN in biochar $i$ and replicate $j$ with an expectation value of 0 . The performance of the model was reported as information criteria (AIC, BIC, -log likelihood, RMSE).

\section{Results}

\subsection{Adsorption Experiment}

\subsubsection{Total Nitrogen}

In the adsorption experiment, the TN concentrations in the birch biochar treatments decreased to $0.45 \mathrm{mg} \mathrm{L}^{-1}$, 
$0.99 \mathrm{mg} \mathrm{L}^{-1}, 1.60 \mathrm{mg} \mathrm{L}^{-1}$, and $2.14 \mathrm{mg} \mathrm{L}^{-1}$ when the initial concentrations were $1 \mathrm{mg} \mathrm{L}^{-1}, 2 \mathrm{mg} \mathrm{L}^{-1}, 3 \mathrm{mg}$ $\mathrm{L}^{-1}$, and $4 \mathrm{mg} \mathrm{L}^{-1}$, respectively (Fig. 1). Whereas for the spruce biochar, the TN concentrations were $0.52 \mathrm{mg} \mathrm{L}^{-1}, 1.13 \mathrm{mg} \mathrm{L}^{-1}, 1.77 \mathrm{mg} \mathrm{L}^{-1}$, and $2.45 \mathrm{mg}$ $\mathrm{L}^{-1}$ at the end of the experiment for initial concentrations of $1 \mathrm{mg} \mathrm{L}^{-1}, 2 \mathrm{mg} \mathrm{L}^{-1}, 3 \mathrm{mg} \mathrm{L}^{-1}$, and $4 \mathrm{mg} \mathrm{L}^{-1}$, respectively (Fig. 1). The concentration decrease during the experiment indicated the adsorption of TN.

Adsorption of $\mathrm{TN}$ was detected in all biochar treatments, and the adsorption amount during the experiment depended on the initial TN concentration (Fig. 2, Eq. 2, Table 2). Adsorption amount increased linearly from 0.05 to $0.2 \mathrm{mg} \mathrm{TN} \mathrm{g}^{-1}$ biochar for spruce and from 0.07 to $0.3 \mathrm{mg} \mathrm{TN} \mathrm{g}^{-1}$ biochar for birch (Fig. 2). Birch biochar adsorbed more TN than the spruce biochar (Table 2).

The adsorption kinetics of TN were calculated based on the concentration differences between consecutive water samplings (Table 3). There was rapid adsorption over the first few days; after which, the adsorption slowed down (Fig. 3). The initial concentration and type of biochar did not affect $k_{\text {ad }}$ (Table 3). $Q_{\max }$ was increased with the increasing initial TN concentration. According to the pseudo-first order and second order models, the $Q_{\max }$ was about 3-4 times and 2 times higher for initial concentrations of $4 \mathrm{mg} \mathrm{L}^{-1}$ and $1 \mathrm{mg}$ $\mathrm{L}^{-1}$, respectively. Birch biochar had a higher $Q_{\max }$ than spruce biochar (Table 3 ). The adsorption process was more consistent in the higher concentrations (Fig. 3).
Fig. 1 Mean $( \pm S D)$ TN concentrations in water with initial concentrations $1 \mathrm{mg}$ $\mathrm{L}^{-1}, 2 \mathrm{mg} \mathrm{L}^{-1}, 3 \mathrm{mg} \mathrm{L}^{-1}$, and $4 \mathrm{mg} \mathrm{L}^{-1}$ in birch and spruce biochar treatments during the 173-h experiment

Fig. 2 TN adsorption amount during the experiment for birch and spruce biochar as a function of initial TN concentrations. Dashed lines represent TN adsorption during $173 \mathrm{~h}$ predicted by the linear mixed-effects model (Table 2)
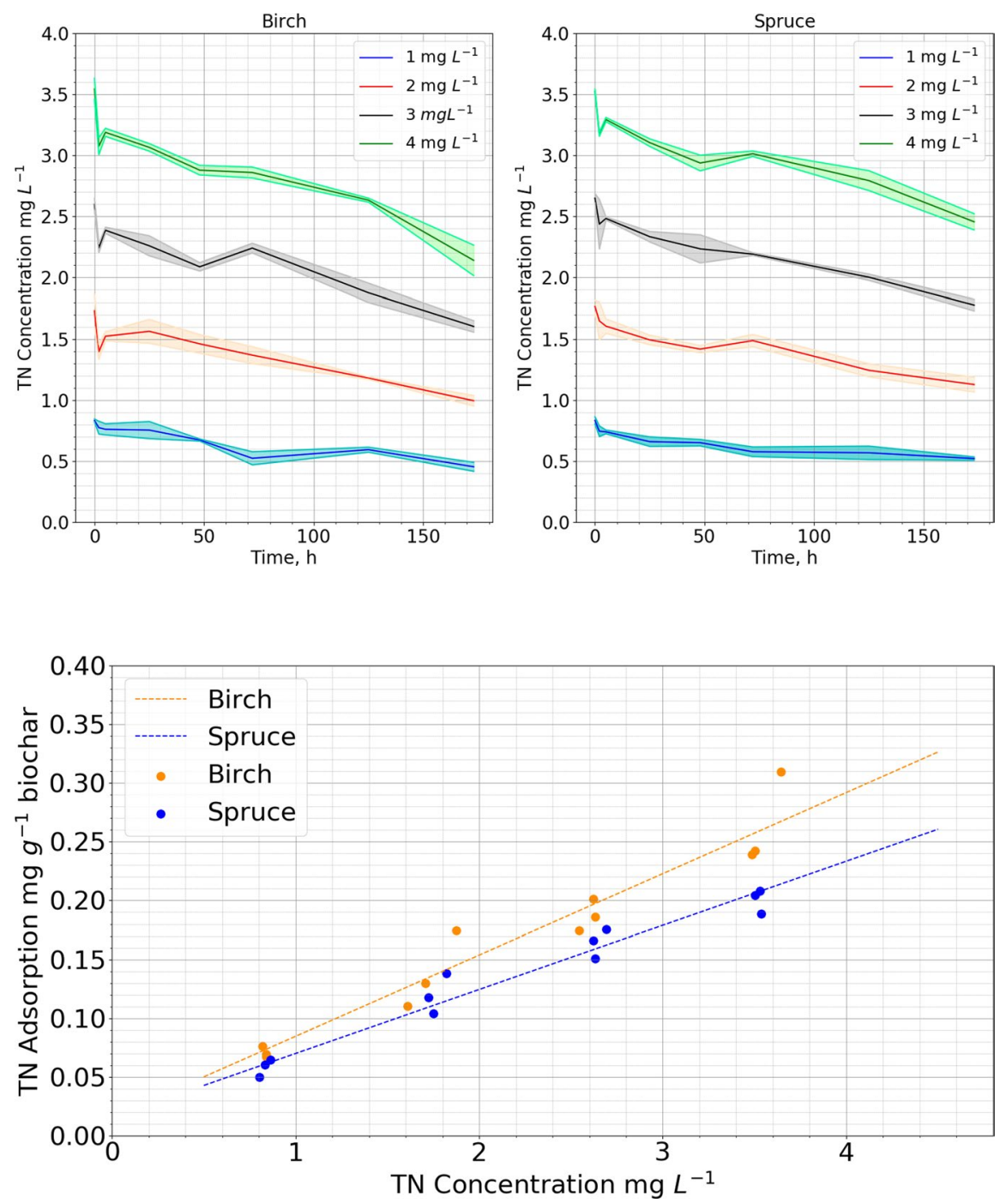
Table 2 Parameter estimates, standard errors of the mean, degrees of freedom, $p$-values, and performance criteria of linear mixed-effect models for TN (Eq. 2)

\begin{tabular}{lcllc}
\hline & \multicolumn{1}{c}{ Value } & Std. error & DF & $p$-value \\
\hline$\alpha$ & 0.015 & 0.008 & 19 & $\mathbf{0 . 0 5 0}$ \\
$\beta_{B b}$ & 0.069 & 0.003 & 19 & $<\mathbf{0 . 0 0 1}$ \\
$\beta_{S b}$ & 0.054 & 0.003 & 19 & $<\mathbf{0 . 0 0 1}$ \\
RMSE (mg TN & 0.014 & - & - & - \\
$\quad$ g biochar $^{-1}$ ) & & & & - \\
AIC & -94.140 & - & - & - \\
logLikelihood & 52.070 & - & - & - \\
$F$-value & 194.26 & - & - & - \\
Residual & 0.016 & - & - & \\
\hline
\end{tabular}

Bold values are statistically significant.

\subsubsection{Inorganic nitrogen}

The initial $\mathrm{NO}_{3}{ }^{-}-\mathrm{N}$ concentrations were $0.3,0.67$, 0.98 , and $1.31 \mathrm{mg} \mathrm{L}^{-1}$ in the treatments where the initial $\mathrm{TN}$ concentrations were $1 \mathrm{mg} \mathrm{L}^{-1}, 2 \mathrm{mg} \mathrm{L}^{-1}$,
$3 \mathrm{mg} \mathrm{L}{ }^{-1}$, and $4 \mathrm{mg} \mathrm{L}^{-1}$, respectively. The $\mathrm{NO}_{3}{ }^{-}-\mathrm{N}$ concentration in the birch biochar treatments decreased to $0.041 \mathrm{mg} \mathrm{L}^{-1}, 0.59 \mathrm{mg} \mathrm{L}^{-1}, 0.54 \mathrm{mg}$ $\mathrm{L}^{-1}$, and $0.64 \mathrm{mg} \mathrm{L}^{-1}$ (Fig. 4). For the spruce biochar, the $\mathrm{NO}_{3}{ }^{-}-\mathrm{N}$ concentrations were $0.02 \mathrm{mg} \mathrm{L}^{-1}$, $0.22 \mathrm{mg} \mathrm{L}^{-1}, 0.92 \mathrm{mg} \mathrm{L}^{-1}$, and $1.06 \mathrm{mg} \mathrm{L}^{-1}$ at the end of the experiment (Fig. 4). The $\mathrm{NO}_{3}{ }^{-}-\mathrm{N}$ concentration decreased during the experiment indicating adsorption of $\mathrm{NO}_{3}{ }^{-}-\mathrm{N}$. The decrease in $\mathrm{NO}_{3}{ }^{-}-\mathrm{N}$ concentration was most evident for the birch biochar with an initial TN concentration of $4 \mathrm{mg} \mathrm{L}^{-1}$ (Fig. 4).

For the birch biochar, the adsorption amount of $\mathrm{NO}_{3}{ }^{-}-\mathrm{N}$ increased linearly from 0 to $0.15 \mathrm{mg}$ $\mathrm{NO}_{3}{ }^{-} \mathrm{N}\left(\mathrm{g}^{-1}\right.$ biochar) when the initial concentration of $\mathrm{NO}_{3}{ }^{-}-\mathrm{N}$ increased from 0.2 to $1.4 \mathrm{mg} \mathrm{L}^{-1}$ (Fig. 5, Table 4). However, in spruce biochar, the initial concentration did not affect $\mathrm{NO}_{3}{ }^{-}-\mathrm{N}$ adsorption (Fig. 5, Table 4).

The concentrations of $\mathrm{NH}_{4}^{+}-\mathrm{N}$ were below the detection limit $\left(0.02 \mathrm{mg} \mathrm{L}^{-1}\right)$ throughout the experiment; and therefore, it was not possible to examine
Table 3 Parameter estimates of pseudo-first order and pseudo-second order models for $\mathrm{TN}$ in different treatments

\begin{tabular}{lllllll}
\hline Biochar & Model & Parameter & \multicolumn{4}{l}{ Initial concentration $\left(\mathrm{mg} \mathrm{L}^{-1}\right)$} \\
\cline { 3 - 6 } & & & 1 & 2 & 3 & 4 \\
\hline \multirow{2}{*}{ Birch } & \multirow{2}{*}{ Pseudo-first order } & $\operatorname{kad}_{1}\left(\mathrm{~h}^{-1}\right)$ & 0.017 & 0.015 & 0.022 & 0.024 \\
& \multirow{3}{*}{ Spruce } & $Q \mathrm{max}_{1}\left(\mathrm{mg} \mathrm{g}^{-1}\right)$ & 0.059 & 0.120 & 0.140 & 0.190 \\
& \multirow{3}{*}{ Pseudo-second order } & $\operatorname{kad}_{2}\left(\mathrm{mg} \mathrm{h}^{-1}\right)$ & 0.190 & 0.130 & 1.050 & 0.820 \\
& \multirow{3}{*}{ Pseudo-first order } & $Q \max _{2}\left(\mathrm{mg} \mathrm{g}^{-1}\right)$ & 0.079 & 0.140 & 0.120 & 0.170 \\
& & $\operatorname{kad}_{1}\left(\mathrm{~h}^{-1}\right)$ & 0.038 & 0.033 & 0.027 & 0.170 \\
& \multirow{2}{*}{ Pseudo-second order } & $Q \max _{1}\left(\mathrm{mg} \mathrm{g}^{-1}\right)$ & 0.051 & 0.084 & 0.110 & 0.120 \\
& & $\operatorname{kad}_{2}\left(\mathrm{mg} \mathrm{h}^{-1}\right)$ & 1.490 & 0.750 & 0.350 & 1.400 \\
& & $Q \max _{2}\left(\mathrm{mg} \mathrm{g}^{-1}\right)$ & 0.054 & 0.089 & 0.120 & 0.130 \\
\hline
\end{tabular}
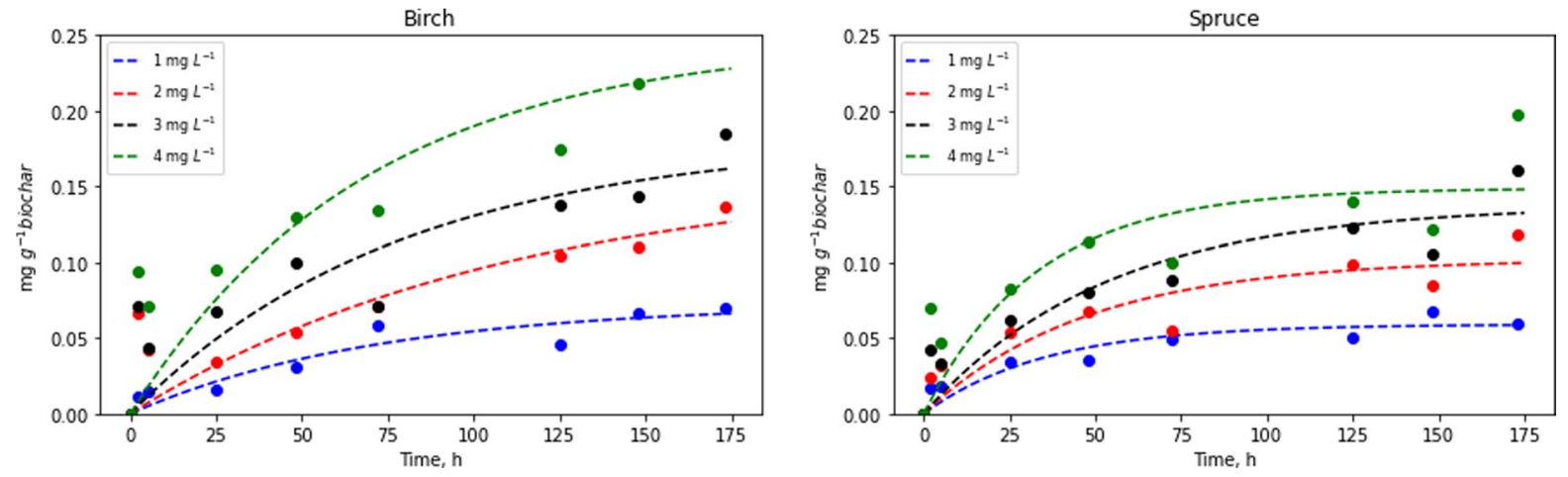

Fig. 3 Adsorption of TN for birch and spruce biochars with different initial TN concentrations in water. The dashed lines represent pseudo-first order adsorption model (Eq. 2) 
Fig. 4 Mean $( \pm S D)$ nitrate-nitrogen $\left(\mathrm{NO}_{3}{ }^{-}-\mathrm{N}\right)$ concentration in water with initial total nitrogen concentrations of $1 \mathrm{mg} \mathrm{L}^{-1}, 2 \mathrm{mg}$ $\mathrm{L}^{-1}, 3 \mathrm{mg} \mathrm{L}^{-1}$, and $4 \mathrm{mg}$ $\mathrm{L}^{-1}$ for birch and spruce biochar treatments during the 173-h experiment
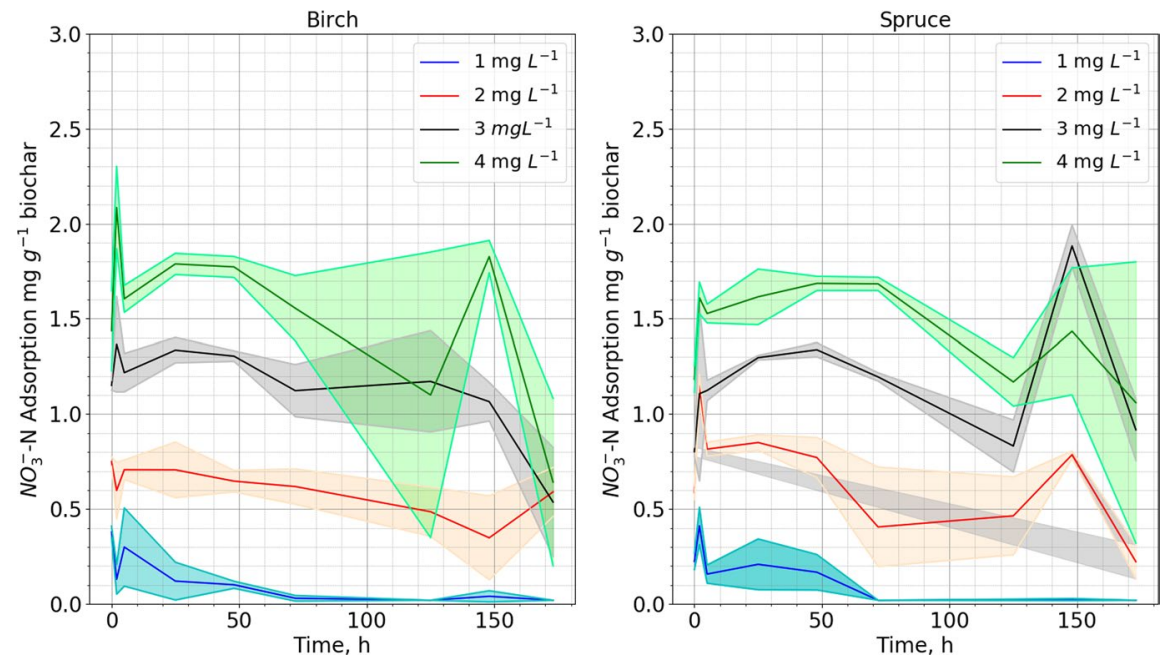

Fig. $5 \mathrm{NO}_{3}{ }^{-}-\mathrm{N}$ adsorption amount for birch and spruce biochar as a function of initial $\mathrm{NO}_{3}{ }^{-}-\mathrm{N}$ concentrations. Dashed lines represent the adsorption amount at $173 \mathrm{~h}$ $\left(A_{173 \mathrm{~h}}\right)$

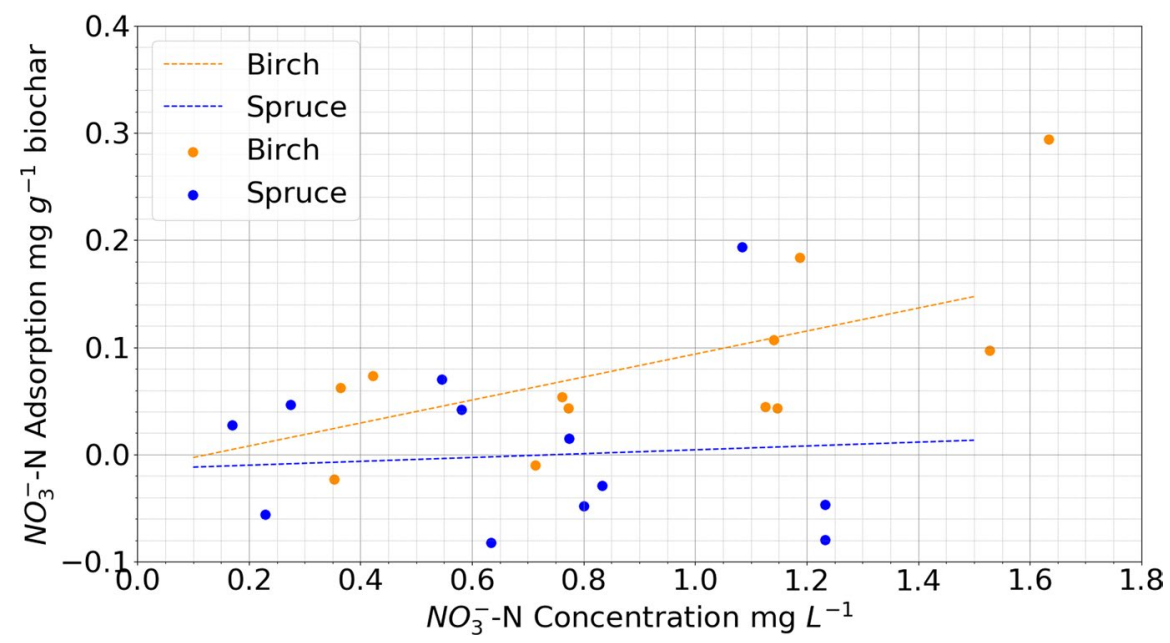

the concentration changes and adsorption parameters for $\mathrm{NH}_{4}{ }^{+}-\mathrm{N}$.

\subsection{Desorption Experiment}

In the adsorption phase, biochar was shaken in initial $\mathrm{TN}$ concentrations of $1 \mathrm{mg} \mathrm{L}^{-1}, 2 \mathrm{mg} \mathrm{L}^{-1}, 3 \mathrm{mg} \mathrm{L}^{-1}$, and $4 \mathrm{mg} \mathrm{L}^{-1}$; after which, the biochars were transferred to lower TN concentrations $(0.2$ and $0.35 \mathrm{mg}$ $\mathrm{L}^{-1}$ ) to study the desorption. TN desorption amount of birch biochar depended on the initial TN concentration in the adsorption phase, and the desorption was significantly different between the spruce and birch biochar (Table 5A, B). In $0.35 \mathrm{mg} \mathrm{L}^{-1}$, the (Table 5B) spruce kept adsorbing $\mathrm{TN}$ also during the desorption phase of the experiment indicated by the negative values of
Table 4 Parameter estimates, standard errors of the mean, degrees of freedom, $p$-values, and performance criteria of linear mixed-effect models for $\mathrm{NO}_{3}{ }^{-}-\mathrm{N}$

\begin{tabular}{lllll}
\hline & Value & Std. error & DF & $p$-value \\
\hline$\alpha$ & -0.013 & 0.035 & 19 & 0.710 \\
$\beta_{B b}$ & 0.107 & 0.038 & 19 & $\mathbf{0 . 0 1 1}$ \\
$\beta_{S b}$ & 0.017 & 0.049 & 19 & 0.720 \\
$\mathrm{RMSE}^{-\mathrm{mg}}$ & 0.069 & - & - & - \\
$\mathrm{NO}_{3}^{-}-\mathrm{Ng}$ & & & & \\
biochar $^{-1}$ ) & & & & \\
$\mathrm{AIC}$ & -33.700 & - & - & - \\
logLikelihood & 21.850 & - & - & - \\
$F$-value & 6.340 & - & - & - \\
Residual & 0.074 & - & - & - \\
\hline
\end{tabular}

The bold value is statistically significant. 
desorption amount (Fig. 6B). Birch biochar had a predominantly higher TN desorption amount when the TN concentration was higher than $1.8 \mathrm{mg} \mathrm{L}^{-1}$ (Fig. 6A, B). The birch biochar desorption was associated with the TN adsorption in smaller initial concentrations (Fig. 6C). Birch biochar released TN for adsorption higher than $0.04 \mathrm{mg} \mathrm{g}^{-1}$ biochar (Fig. 6C, 6D). The desorption difference for spruce biochar was not significant in smaller and higher concentrations (Table 5C, D, Fig. 6). TN desorption amount of birch biochar was associated with the $\mathrm{TN}$ adsorption (Table 5C, D). For spruce, the $\mathrm{TN}$ desorption amount in $0.2 \mathrm{mg} \mathrm{L}^{-1}$ was very low (Fig. 6A, C). The desorption process was more consistent for birch biochar in both 0.2 and $0.35 \mathrm{mg} \mathrm{L}^{-1}$ (Fig. 6). This suggests that the desorption process was dependent on the initial concentration.

\section{Discussion}

The current study showed that birch and spruce biochar effectively adsorbed $\mathrm{TN}$ and $\mathrm{NO}_{3}{ }^{-}-\mathrm{N}$ in forest

Table 5 Parameter estimates, standard errors of the mean, degrees of freedom, $p$-values, and performance criteria of linear mixed-effects models for TN desorption (Eq. 6) in the concentration of $0.2 \mathrm{mg} \mathrm{L}^{-1}$ treatments (left: A and C) and runoff waters. Our results support previous studies by Saarela et al. (2020) and Kakaei Lafdani et al. (2020). The adsorption amount of spruce and birch biochar increased with the increasing TN concentration in water (Figs. 2 and 3), which is probably due to the increased $\mathrm{N}$ availability in the solution and increased TN concentration gradient along the flow path from the solution to external surfaces and finally to internal surfaces of biochar (Lagritte \& Pasquier, 2016; Ahmadvand et al., 2018). The results are consistent with the results obtained by Ahmadvand et al. (2018) and Saarela et al. (2020), showing that with an increase in the initial N concentration of the solution, the adsorption amount of biochar tends to increase. The low initial concentrations of $\mathrm{NH}_{4}{ }^{+}-\mathrm{N}\left(<0.02 \mathrm{mg} \mathrm{L}^{-1}\right)$ was the reason why we could not determine the adsorption parameters for this compound, but based on the literature, it is known that biochar is an effective adsorbent for $\mathrm{NH}_{4}{ }^{+}-\mathrm{N}$ (Wang et al., 2015; Takaya et al., 2016; Yin et al., 2017). The surfaces of carbon-based materials are generally negatively charged (Krishnan \& Haridas, 2008; Yao et al., 2011), which is thought to make them poor adsorbents

$0.35 \mathrm{mg} \mathrm{L}^{-1}$ treatments (right: B and D). The parameters $\alpha$ and $\beta$ represent birch biochar and the parameters for spruce biochar are obtained as $\left(\alpha+\alpha_{S}\right)$ and $\left(\beta+\beta_{S}\right)$

\begin{tabular}{|c|c|c|c|c|c|c|c|c|c|}
\hline A & Value & Std. error & DF & $p$-value & B & Value & Std. error & DF & $p$-value \\
\hline$\alpha$ & -0.003 & $<0.001$ & 18 & $<0.001$ & $\alpha$ & -0.003 & $<0.001$ & 18 & 0.003 \\
\hline$\alpha_{s}$ & 0.004 & $<0.001$ & 18 & $<0.001$ & $\alpha_{s}$ & 0.001 & $<0.001$ & 18 & 0.370 \\
\hline$\beta$ & 0.001 & $<0.001$ & 18 & $<0.001$ & $\beta$ & 0.002 & $<0.001$ & 18 & $<0.001$ \\
\hline$\beta_{S}$ & -0.001 & $<0.001$ & 18 & $<0.001$ & $\beta_{S}$ & -0.001 & $<0.001$ & 18 & 0.007 \\
\hline RMSE & 0.001 & - & - & - & RMSE & 0.001 & - & - & - \\
\hline AIC & -209.967 & - & - & - & AIC & -187.107 & - & - & - \\
\hline logLikelihood & 110.983 & - & - & - & logLikelihood & 99.553 & - & - & - \\
\hline$F$-value & 39.88 & - & - & - & $F$-value & 22.739 & - & - & - \\
\hline Residual & 0.001 & - & - & - & Residual & 0.001 & - & - & - \\
\hline $\mathrm{C}$ & Value & Std. error & DF & $p$-value & $\mathrm{D}$ & Value & Std. error & DF & $p$-value \\
\hline$\alpha$ & -0.001 & 0.001 & 18 & 0.150 & $\alpha$ & -0.002 & 0.001 & 18 & 0.290 \\
\hline$\alpha_{s}$ & 0.002 & 0.001 & 18 & 0.040 & $\alpha_{s}$ & 0.001 & 0.001 & 18 & 0.740 \\
\hline$\beta$ & 0.040 & 0.014 & 18 & 0.020 & $\beta$ & 0.039 & 0.019 & 18 & 0.060 \\
\hline$\beta_{S}$ & -0.037 & 0.021 & 18 & 0.110 & $\beta_{S}$ & -0.04 & 0.028 & 18 & 0.170 \\
\hline RMSE & 0.001 & - & - & - & RMSE & 0.001 & - & - & - \\
\hline AIC & -198.781 & - & - & - & AIC & -187.278 & - & - & - \\
\hline logLikelihood & 105.390 & - & - & - & logLikelihood & 99.643 & - & - & - \\
\hline$F$-value & 0.004 & - & - & - & $F$-value & 0.002 & - & - & - \\
\hline Residual & 0.001 & - & - & - & Residual & 0.001 & - & - & - \\
\hline
\end{tabular}

Bold values are statistically significant. 

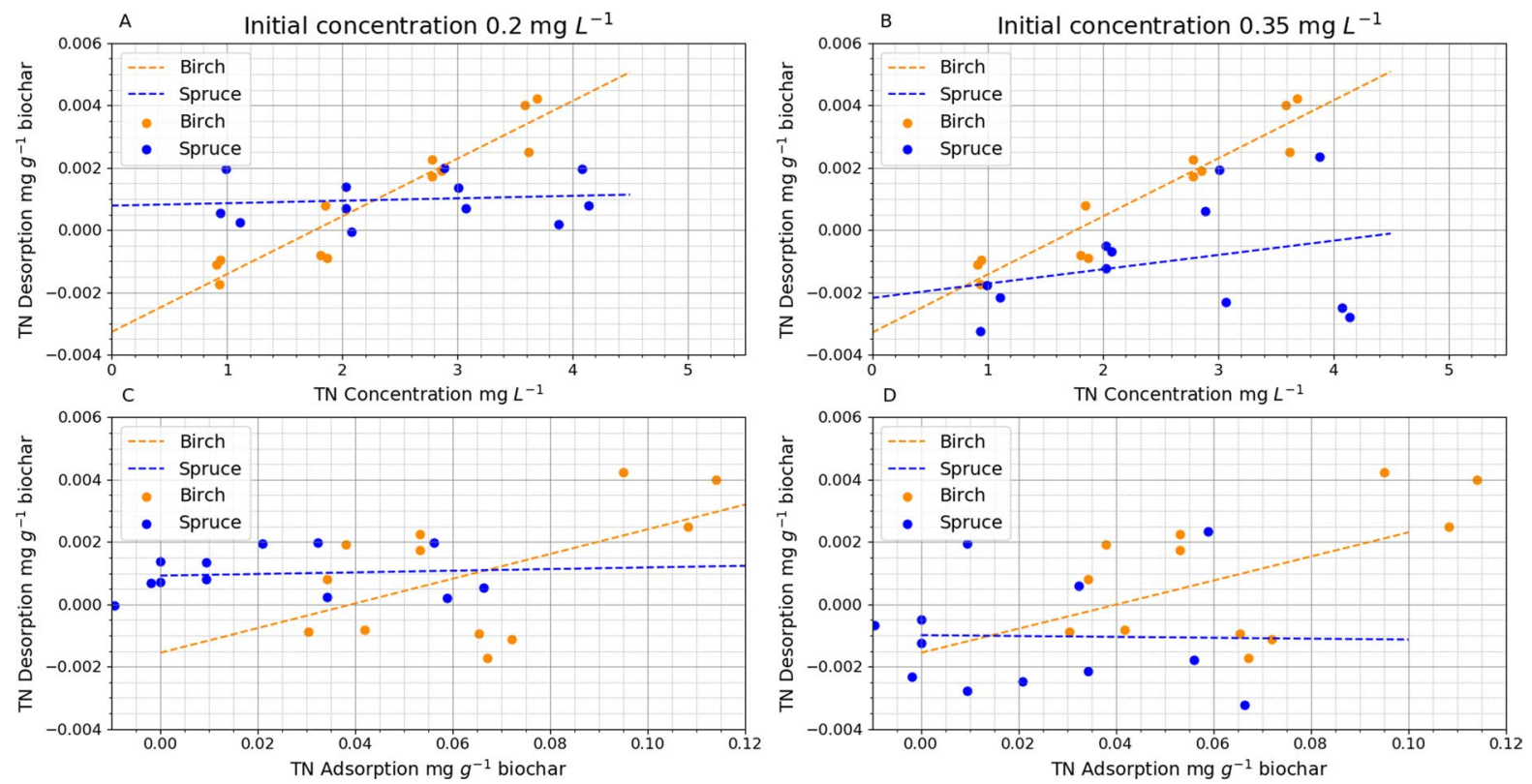

Fig. $6 \mathrm{TN}$ desorption amount for birch and spruce biochar treatments and initial TN concentration of $0.2 \mathrm{mg} \mathrm{L} \mathrm{L}^{-1}$ (left) and $0.35 \mathrm{mg}$ $\mathrm{L}^{-1}$ (right)

of negatively charged ions. Also, positively charged ions attached to the biochar surface increase the adsorption of anions with electrostatic interactions (Premarathna et al., 2019). In our experiments, the adsorption of $\mathrm{NO}_{3}{ }^{--} \mathrm{N}$ (Table 4, Fig. 5) took place which indicates that biochar is capable of adsorbing anions, which is consistent with the results of Chintala et al. (2013) and Cai et al. (2016). In general, adsorption of ions onto the biochar surfaces can be categorized into 4 different classes: precipitation (salt precipitation), chemical adsorption (chemical reaction with surface functional groups), physical adsorption (entrapped in the solution present in interior pores), or electrostatic adsorption (cation or anion exchange to charged functional groups on biochar surfaces) (Fidel et al., 2018; Haider et al., 2016; Noel et al., 2007). Biochar's capacity to adsorb $\mathrm{NO}_{3}{ }^{-}-\mathrm{N}$ is often attributed to its high surface area and porosity and positively charged functional groups (Fidel et al., 2018). $\mathrm{NO}_{3}{ }^{-}-\mathrm{N}$ adsorption has been shown to increase with increasing biochar pyrolysis temperature and decreasing $\mathrm{pH}$, likely reflecting an anion exchange adsorption mechanism (Fidel et al., 2018). Previous studies have reported mixed results about the biochar capacity to adsorb anions. Some studies have shown that biochar also effectively adsorbed $\mathrm{NO}_{3}{ }^{-}-\mathrm{N}$ (Ahmadvand et al., 2018; Chintala et al., 2013) through its numerous functional groups, such as carboxylic, hydroxyl, lactone, and ketone groups (Cai et al., 2016). Chintala et al. (2013) reported that with decreasing liquid $\mathrm{pH}$, biochar can adsorb more $\mathrm{NO}_{3}{ }^{-}-\mathrm{N}$ because due to protonation reaction, the biochar surfaces become more positively charged. However, when the solution contains high concentrations of other anions, the competitive adsorption decreases the adsorption of $\mathrm{NO}_{3}{ }^{-}-\mathrm{N}$ (Chintala et al., 2013).

Nevertheless, the inability or weak ability of biochar to adsorb $\mathrm{N}$ compounds has been reported as well (Hollister et al., 2013). Yao et al. (2012) reported that among 13 different kinds of biochars, only 2 types of biochars were able to adsorb $\mathrm{NO}_{3}{ }^{-}-\mathrm{N}$. Gai et al. (2014) showed some $\mathrm{NO}_{3}{ }^{-}-\mathrm{N}$ was even released from the biochar. The inconsistency among the results can be explained by various preparation conditions, different characteristics of biochar produced from differing biomass, as well as various initial concentrations of $\mathrm{N}$ compounds in the solution.

The interaction between the adsorbents and adsorbates at equilibrium can be described using kinetic models. Pseudo-first and second-order kinetic models consider chemical adsorption mechanisms between the adsorbate and adsorbent and provide valuable information on adsorption rate and maximum 
adsorption capacity (Zhao et al., 2018). In the current study, both models showed rather similar performance against the experimental data (Fig. 3, Table 3). The maximum adsorption capacity at equilibrium, $Q_{\max }$, was increased with increasing $\mathrm{TN}$ concentrations in the solution. Similar results were also reported by other researchers where maximum adsorption capacity increased with the increasing initial concentration of $\mathrm{N}$ (Milmile et al., 2011; Olgun et al., 2013). The pseudofirst order model results showed that the adsorption rate, $k_{\text {ad }}$, of spruce biochar decreased by increasing $Q_{\max }$ (Table 3). The pseudo-second order kinetic model assumes that the rate-limiting step is the interaction between adsorbate and adsorbent, and it is usually used to describe chemical adsorption (Zhen et al., 2015). According to the kinetic models' results, the $Q_{\max 1}$ was about 3-4 times and $Q_{\max 2}$ was 2 times higher for TN concentration $4 \mathrm{mg} \mathrm{L}^{-1}$ compared to $1 \mathrm{mg} \mathrm{L}^{-1}$.

Our results imply that birch biochar has predominantly higher $Q_{\max }$ than spruce biochar (Fig. 3) which is consistent with the results obtained by Saarela et al. (2020). Despite the higher specific surface area of spruce biochar $\left(320 \mathrm{~m}^{2} \mathrm{~g}^{-1}\right)$ compared to birch biochar $\left(260 \mathrm{~m}^{2} \mathrm{~g}^{-1}\right)$, the results demonstrated that $Q_{\max }$ was higher with birch biochar than spruce biochar (Table 3). This indicates that $\mathrm{N}$ maximum adsorption capacity is not exclusively dependent on the biochar surface area (Saarela et al., 2020; Takaya et al., 2016; Zhang et al., 2012, 2014). $Q_{\max }$ increased with the increasing TN concentration, which can be due to $\mathrm{N}$ availability in solution with higher initial concentrations (Lagritte \& Pasquier, 2016).

The desorption amount was significantly higher in birch biochar than spruce biochar, which agreed with the higher birch biochar adsorption amount. In contrast, spruce biochar showed negative desorption values which indicated TN adsorption instead of desorption. This shows that spruce biochar was not saturated. TN desorption amount increased by increasing the water $\mathrm{TN}$ concentration for birch biochar, which is coherent with the results by Chintala et al. (2013). Mechanisms behind the desorption are connected to lower bond energy with more exchangeable ions in water, entrapment of organic compounds in micropores or pore deformation mechanisms (Braida et al., 2003; Chintala et al., 2013; Dechene et al., 2014; Loganathan et al., 2009; Zhang et al., 2010). Differences between adsorption and desorption isotherms are also reported by Zhu and Selim (2000).
Using biochar in the removal of $\mathrm{N}$ compounds from runoff water in peatland forests can be difficult to predict because of the temporal variation in TN concentrations. The current study showed that despite the maximum adsorption of TN to birch biochar $\left(0.309 \mathrm{mg}\right.$ TN g biochar $\left.^{-1}\right)$, only $1.29 \%$ was desorbed $\left(0.004 \mathrm{mg}\right.$ TN $\mathrm{g}$ biochar $\left.^{-1}\right)$. The amount of released TN by the spruce biochar was only about

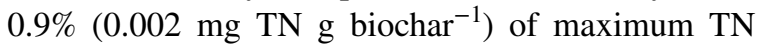
absorbed $\left(0.208 \mathrm{mg} \mathrm{TN} g\right.$ biochar $\left.^{-1}\right)$. The results illustrated that the desorption rate of TN from spruce and birch biochar has been negligible, which makes biochar a promising water protection tool especially in watersheds where the aquatic ecosystems are exposed to high nutrient loads from peatlands.

\section{Conclusions}

This study examined the $\mathrm{N}$ adsorption and desorption behaviors of biochar in peatland forest runoff water. Our results showed efficient adsorption of both organic and inorganic $\mathrm{N}$ from peatland runoff waters. Despite the efficient adsorption, only a small fraction of the adsorbed TN was released through desorption when the biochar was exposed to water with low TN concentrations. The seasonal fluctuation of nutrient concentrations emphasizes the need for an effective water protection tool in peatland forestry to which adsorption-based nutrient removal with biochar seems to be an effective water protection tool. Therefore, biochar provides an optional way to runoff water purification in forested peatland areas for times when traditional water protection methods are inefficient.

Acknowledgements The authors would like to thank Marja Noponen for her guidance in the laboratory analyses.

Author Contribution Marjo Palviainen, Ari Laurén, and Elham Kakaei Lafdani developed the idea and designed the study. Elham Kakaei Lafdani set up the experiment, conducted the laboratory work, analyzed the data, and wrote the article. Jovana Cvetkovic participated in the laboratory work. Taija Saarela performed the laboratory work and commented on the manuscript. Jukka Pumpanen, Marjo Palviainen, and Ari Laurén participated in writing and editing the text. Marjo Palviainen and Jukka Pumpanen were responsible for the funding acquisition. All authors have read and agreed to the published version of the manuscript.

Funding Open access funding provided by University of Eastern Finland (UEF) including Kuopio University 
Hospital. This study was funded by Marjatta and Eino Kolli Foundation and the Doctoral Programme in Forests and Bioresources (Early Stage Researcher funding), University of Eastern Finland. Writing was performed out with funding from the Academy of Finland to strengthen university research profiles in Finland for the years 2017-2021 (funding decision 311925) and the REFORMWATER project (funding decision 326818).

Availability of Data and Material Data is publicly available in the supplementary materials.

Code Availability N/A.

Declarations

Conflict of Interest The authors declare no competing interests.

Fig. 7 Experimental design and the flowchart of the adsorption experiment
Open Access This article is licensed under a Creative Commons Attribution 4.0 International License, which permits use, sharing, adaptation, distribution and reproduction in any medium or format, as long as you give appropriate credit to the original author(s) and the source, provide a link to the Creative Commons licence, and indicate if changes were made. The images or other third party material in this article are included in the article's Creative Commons licence, unless indicated otherwise in a credit line to the material. If material is not included in the article's Creative Commons licence and your intended use is not permitted by statutory regulation or exceeds the permitted use, you will need to obtain permission directly from the copyright holder. To view a copy of this licence, visit http://creativecommons.org/licenses/by/4.0/.

\section{Appendix}

\section{Collecting runoff water from a ditch drained clear-cut peatland forest}

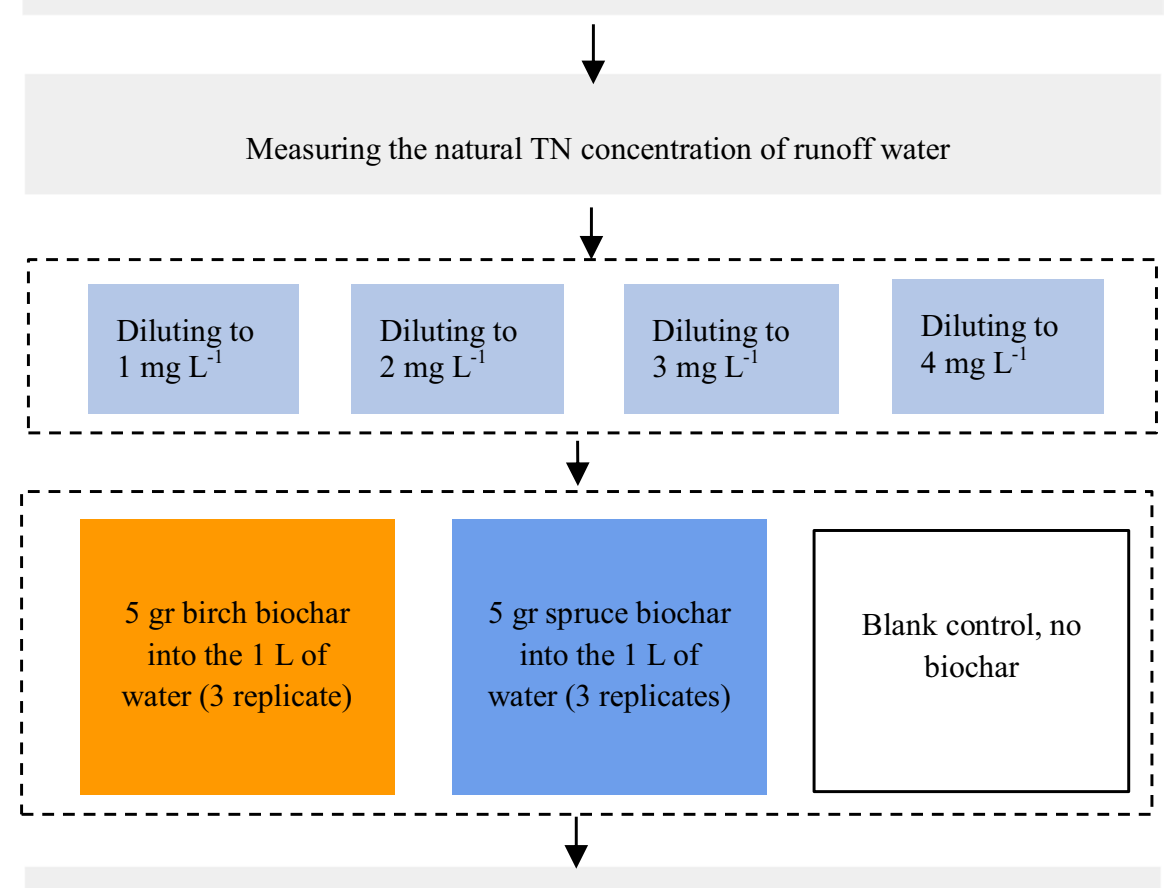

Shaking water samples and taking $30 \mathrm{~mL}$ water sample at points of time: $0,2,5,25$, $48,72,125$, and 173 hours from the beginning of the experiment

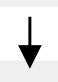

Filtering water samples, and analysis of $\mathrm{TN}, \mathrm{NO}_{3}{ }^{-}-\mathrm{N}$ and $\mathrm{NH}_{4}{ }^{+}-\mathrm{N}$ 
Fig. 8 Experimental design and the flowchart of the desorption experiment

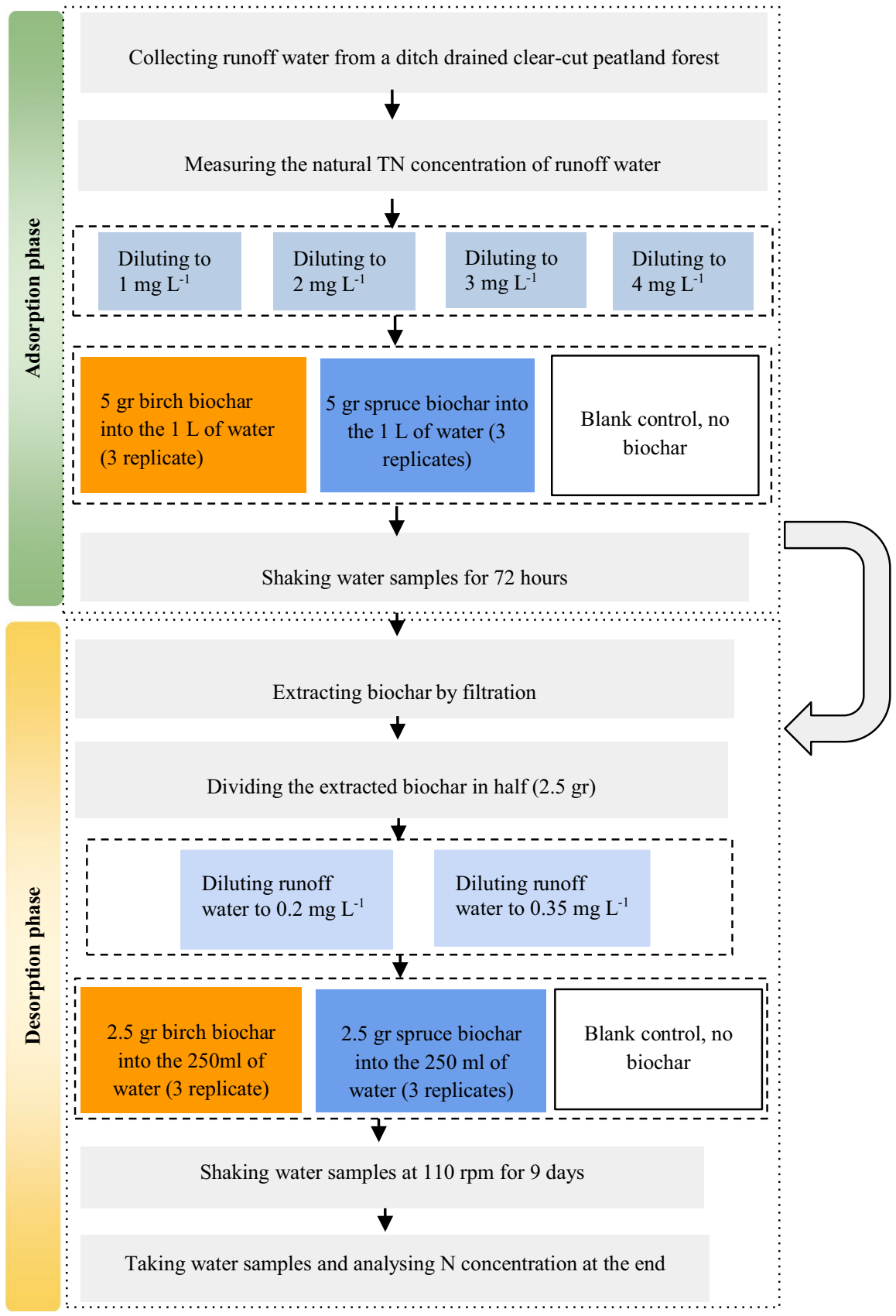




\section{References}

Accardi-Dey, A., \& Gschwend, P. M. (2003). Reinterpreting literature sorption data considering both absorption and adsorption into organic carbon and adsorption onto black carbon. Environmental Science \& Technology, 37, 99-106. https://doi.org/10.1021/es020569v

Ahmadvand, M., Soltani, J., Hashemi Garmdareh, S. E., \& Varavipour, M. (2018). The relationship between the characteristics of biochar produced at different temperatures and its impact on the uptake of $\mathrm{NO}_{3}$. Environmental Health Engineering and Management, 5, 67-75. https:// doi.org/10.15171/EHEM.2018.10

Battas, A., El Gaidoumi, A., Ksakas, A., \& Kherbeche., A. . (2019). Adsorption study for the removal of nitrate from water using local clay. The Scientific World Journal, 2019, 1-10. https://doi.org/10.1155/2019/9529618

Beesley, L., Moreno-Jiménez, E., Gomez-Eyles, J., \& 1., Harris, E., Robinson, B., \& Sizmur, T. . (2011). A review of biochars' potential role in the remediation, revegetation and restoration of contaminated soils. Environmental Pollution, 159(12), 3269-3282. https://doi.org/10. 1016/j.envpol.2011.07.023

Braida, W. J., Pignatello, J. J., Lu, Y., Ravikovitch, P. I., Neimark, A. V., \& Xing, B. (2003). Sorption hysteresis of benzene in charcoal particles. Environmental Science \& Technology, 37, 409-417. https://doi.org/10.1021/es020 $660 \mathrm{z}$

Cai, Y., Qi, H., Liu, Y., \& He, X. (2016). Sorption/desorption behavior and mechanism of $\mathrm{NH}_{4}{ }^{+}$by biochar as a nitrogen fertilizer sustained-release material. Journal of Agricultural and Food Chemistry, 64(24), 4958-4964. https://doi.org/10.1021/acs.jafc.6b00109

Chintala, R., Mollinedo, J., Schumacher, T. E., Papiernik, Sh. K., Malo, D. D., Clay, D. E., et al. (2013). Nitrate sorption and desorption in biochars from fast pyrolysis. Microporous and Mesoporous Materials, 179, 250-257. https://doi.org/10.1016/j.micromeso.2013.05.023

Dechene, A., Rosendahl, I., Laabs, V., \& Amelung, W. (2014). Sorption of polar herbicides and herbicide metabolites by biochar-amended soil. Chemosphere, 109, 180-186. https://doi.org/10.1016/j.chemosphere. 2014.02.010

Fawcett, j. k., Scott, J. (1960). A rapid and precise method for the determination of urea. Journal of Clinical Pathology, 13(2), 156-159. https://doi.org/10.1136/jcp. 13.2.156.

Fidel, R. B., Laird, D. A., \& Spokas, K. A. (2018). Sorption of ammonium and nitrate to biochars is electrostatic and $\mathrm{pH}-$ dependent. Scientific Reports, 8, 17627. https://doi.org/10. 1038/s41598-018-35534-w

Finér, L., Lepistö, A., Karlsson, K., Räike, A., Härkönen, L., Huttunen, M., et al. (2021). Drainage for forestry increases $\mathrm{N}, \mathrm{P}$ and TOC export to boreal surface waters. Science of the Total Environment, 762, 144098. https://doi.org/10. 1016/j.scitotenv.2020.144098

Gai, X., Wang, H., Liu, J., Zhai, L., Liu, S., Ren, T., \& Liu, H. (2014). Effects of feedstock and pyrolysis temperature on biochar adsorption of ammonium and nitrate. PLOS ONE,
9(12), e113888. https://doi.org/10.1371/journal.pone. 0113888

Gaunt, J., \& Lehmann, J. (2008). Energy balance and emissions associated with biochar sequestration and pyrolysis bioenergy production. Environmental Science \& Technology, 42, 4152-4158. https://doi.org/10.1021/es071361i

Haider, G., Steffens, D., Müller, C., \& Kammann, C. I. (2016). Standard extraction methods may underestimate nitrate stocks captured by field-aged biochar. Journal of Environmental Quality, 45(4), 1196-1204. https://doi.org/10. 2134/jeq2015.10.0529

Hollister, C. C., Bisogni, J. J., \& Lehmann, J. (2013). Ammonium, nitrate, and phosphate sorption to and solute leaching from biochars prepared from corn Stover (L.) and Oak Wood (spp.). Journal of Environmental Quality, 42, 137144. https://doi.org/10.2134/jeq2012.0033

Hytönen, J., Hökkä, H., \& Saarinen, M. (2020). The effect of planting, seeding and soil preparation on the regeneration success of Scots pine (Pinus sylvestris L.) on drained peatlands - 10- year results. Forestry Studies, 72(1), 91-106. https://doi.org/10.2478/fsmu-2020-0008

Jin, H., Hanif, M. U., Capareda, S., Chang, Z., Huang, H., \& Ai, Y. (2016). Copper (II) removal potential from aqueous solution by pyrolysis biochar derived from anaerobically digested algae-dairy-manure and effect of $\mathrm{KOH}$ activation. Journal of Environmental Chemical Engineering, 4(1), 365-372. https://doi.org/10.1016/j.jece.2015.11.022

Joensuu, S., Ahti, E., \& Vuollekoski, M. (2002). Effects of ditch network maintenance on the chemistry of run-off water from peatland forests. Scandinavian Journal of Forest Research, 17(3), 238-247. https://doi.org/10.1080/ 028275802753742909

Kakaei Lafdani, E., Saarela, T., Laurén, A., Pumpanen, J., \& Palviainen, M. (2020). Purification of forest clear-cut runoff water using biochar: A meso-scale laboratory Column Experiment. Water, 12(2), 478. https://doi.org/10.3390/ w12020478

Kalvīte, Z., Lībiete, Z., \& Kḷaviṇšm, I. (2019). The efficiency of forest drainage system sedimentation ponds in the context of water quality. Water management. Conference: Research for Rural Development 2019: annual $25^{\text {th }}$ International scientific conference proceedings.

Kookana, R. S. (2010). The role of biochar in modifying the environmental fate, bioavailability, and efficacy of pesticides in soils: A review. Australian Journal of Soil Research, 48(7), 627-637. https://doi.org/10.1071/SR100 07

Krishnan, K. A., \& Haridas, A. (2008). Removal of phosphate from aqueous solutions and sewage using natural and surface modified coir pith. Journal of Hazardous Materials, 152, 527-535. https://doi.org/10.1016/j.jhazmat.2007.07. 015

Lagritte, L., \& Pasquier, R. (2016). A review of the kinetics adsorption models and their application to the adsorption of lead by an activated carbon. Chemical Engineering Research and Design, 109, 495-504. https://doi.org/10. 1016/j.cherd.2016.02.006.

Laird, D., Fleming, P., Wang, B., Horton, R., \& Karlen, D. (2010). Biochar impact on nutrient leaching from a 
Midwestern agricultural soil. Geoderma, 158(3-4), 436442. https://doi.org/10.1016/j.geoderma.2010.05.012

Largitte, L., \& Pasquier, R. (2016). A review of the kinetics adsorption models and their application to the adsorption of lead by an activated carbon. Chemical Engineering Research and Design, 109, 495-504. https://doi.org/10. 1016/j.cherd.2016.02.006

Li, L. Y., Long, K., Zan, Q., Liang, L., \& Shen, G. Q. (2015). Magnetic biochar decorated with $\mathrm{ZnS}$ nanocrystals for $\mathrm{Pb}$ (II) removal. Journal of the American Chemical Society, 3, 125-132. https://doi.org/10.1021/sc500619r

Liljaniemi, P., Vuori, K. M., Tossavainen, T., Kotanen, J., Haapanen, M., Lepistö, A., et al. (2003). Effectiveness of constructed overland flow areas in decreasing diffuse pollution from forest drainages. Environmental Management, 32, 602-613. https://doi.org/10.1007/s00267-003-2927-4

Liu, J., Jiang, S., Chen, D., Dai, G., Wei, D., \& Shu, Y. (2020). Activation of persulfate with biochar for degradation of bisphenol A in soil. Chemical Engineering Journal, 381, 122637. https://doi.org/10.1016/j.cej.2019.122637

Loganathan, V. A., Feng, Y., Sheng, G. D., \& Clement, T. P. (2009). Crop-residue derived char influences sorption, desorption and bioavailability of atrazine in soils. Soil Science Society of America Journal, 73, 967-974. https://doi. org/10.2136/sssaj2008.0208

Marttila, H., \& Kløve, B. (2010). Managing runoff, water quality and erosion in peatland forestry by peak runoff control. Ecological Engineering, 36(7), 900-911. https://doi.org/ 10.1016/j.ecoleng.2010.04.002

Mattsson, T., Kortelainen, P., Räike, A., Lepistö, A., \& Thomas, D. N. (2015). Spatial and temporal variability of organic $\mathrm{C}$ and $\mathrm{N}$ concentrations and export from 30 boreal rivers induced by land use and climate. Science of the Total Environment, 508, 145-154. https://doi.org/10. 1016/j.scitotenv.2014.11.091

Micromeritics Flowsrb II 2300. (1986). Micromeritics Instrument Corporation: Atlanta, GA, USA

Milmile, S. N., Pande, J. V., Karmakar, S., Bansiwal, A., Chakrabarti, T., \& Biniwale, R. B. (2011). Equilibrium isotherm and kinetic modeling of the adsorption of nitrates by anion exchange Indion NSSR resin. Desalination, 276(1-3), 38-44. https://doi.org/10.1016/j.desal. 2011.03.015

Miranda, K. M., Espey, M. G., \& Wink, D. A. (2001). A Rapid Simple Spectrophotometric Method for Simultaneous Detection of Nitrate and Nitrite. Nitric Oxide, 5(1), 62-71. https://doi.org/10.1006/niox.2000.0319.

Mohan, D., Sarswat, A., Ok, Y. S., \& Pittman, C. U., Jr. (2014). Organic and inorganic contaminants removal from water with biochar, a renewable low cost and sustainable adsorbent-a critical review. Bioresource Technology, 160, 191202. https://doi.org/10.1016/j.biortech.2014.01.120

Nieminen, M., Sallantaus, T., Ukonmaanaho, L., Nieminen, T. M., \& Sarkkola, S. (2017). Nitrogen and phosphorus concentrations in discharge from drained peatland forests are increasing. Science of the Total Environment, 609, 974981. https://doi.org/10.1016/j.scitotenv.2017.07.210

Nieminen, M., Ahti, E., Nousiainen, H., Joensuu, S., \& Vuollekoski, M. (2005). Capacity of riparian buffer zones to reduce sediment concentrations in discharge from peatlands drained for forestry. Silva Fennica, 39, 331-339. https://doi.org/10.14214/sf.371

Noel, J. D., Biswas, P., \& Giammar, D. E. (2007). Evaluation of a sequential extraction process used for determining mercury binding mechanisms to coal combustion byproducts. Journal of the Air \& Waste Management Association, 57, 856-867. https://doi.org/10.3155/1047-3289.57.7.856

Olgun, A., Atar, N., \& Wang, S. (2013). Batch and column studies of phosphate and nitrate adsorption on waste solids containing boron impurity. Chemical Engineering Journal, 222, 108-119. https://doi.org/10.1016/j.cej.2013.02.029

Oliveira, R. F., Patel, A. K., Jaisi, D. P., Adhikari, S., Lu, H., \& Khanal, S. K. (2018). Review environmental application of biochar current status and perspectives. Bioresource Technology, 246, 110-122. https://doi.org/10.1016/j.biort ech.2017.08.122

Premarathna, K. S. D., Rajapaksha, A. U., Sarkar, B., Kwon, E. E., Bhatnagar, A., Ok, Y. S., et al. (2019). Biochar-based engineered composites for sorptive decontamination of water: A review. Chemical Engineering Journal, 372, 536-550. https://doi.org/10.1016/j.cej.2019.04.097

Saarela, T., Kakaei Lafdani, E., Laurén, A., Pumpanen, J., \& Palviainen, M. (2020). Biochar as adsorbent in purification of clear-cut forest runoff water: Adsorption rate and adsorption capacity. Biochar, 2, 227-237. https://doi.org/ 10.1007/s42773-020-00049-z

Singh, N. B., Nagpal, G., Agrawal, S., \& Rachna. . (2018). Water purification by using adsorbents: A review. Environmental Technology \& Innovation, 11, 187-240. https:// doi.org/10.1016/j.eti.2018.05.006

Takaya, C. A., Fletcher, L. A., Singh, S., Anyikude, K. U., \& Ross, A. B. (2016). Phosphate and ammonium sorption capacity of biochar and hydrochar from different wastes. Chemosphere, 145, 518-527. https://doi.org/10.1016/j. chemosphere.2015.11.052

Wang, S., Gao, B., Zimmerman, A. R., Li, Y., Ma, L., Harris, W. G., et al. (2015). Removal of arsenic by magnetic biochar prepared from pinewood and natural hematite. Bioresource Technology, 175, 391-395. https://doi.org/10. 1016/j.biortech.2014.10.104

Yao, Y., Gao, B., Inyang, M., Zimmerman, A. R., Cao, X., Pullammanappallil, P., et al. (2011). Removal of phosphate from aqueous solution by biochar derived from anaerobically digested sugar beet tailings. Journal of Hazardous Materials, 190(1-3), 501-507. https://doi.org/10.1016/j. jhazmat.2011.03.083

Yao, Y., Gao, B., Zhang, M., Inyang, M., \& Zimmerman, A. R. (2012). Effect of biochar amendment on sorption and leaching of nitrate, ammonium, and phosphate in a sandy soil. Chemosphere, 89(11), 1467-1471. https://doi.org/10. 1016/j.chemosphere.2012.06.002

Yin, Q., Zhang, B., Wang, R., \& Zhao, Z. (2017). Biochar as an adsorbent for inorganic nitrogen and phosphorus removal from water: A review. Environmental Science and Pollution Research, 24, 26297-26309. https://doi.org/10.1007/ s11356-017-0338-y

Zhang, H., Wang, H., \& Gan, J. (2010). Effect of Pinus radiata derived biochars on soil sorption and desorption of phenanthrene. Environmental Pollution, 158, 2821-2825. https://doi.org/10.1016/j.envpol.2010.06.025 
Zhang, Y., Li, Z. F., \& Mahmood, I. B. (2014). Recovery of $\mathrm{NH}_{4}{ }^{+}$by corn cob produced biochars and its potential application as soil conditioner. Frontiers of Environmental Science \& Engineering, 8, 825-834. https://doi.org/10. 1007/s11783-014-0682-9

Zhang, M., Gao, B., Yao, Y., Xue, Y. W., \& Inyang, M. (2012). Synthesis of porous MgO-biochar nanocomposites for removal of phosphate and nitrate from aqueous solutions. Chemical Engineering Journal, 210, 26-32. https://doi. org/10.1016/j.cej.2012.08.052

Zhao, H., Xue, Y., Long, L., \& Hu, X. (2018). Adsorption of nitrate onto biochar derived from agricultural residuals. Water Science \& Technology, 77(1-2), 548-554. https:// doi.org/10.2166/wst.2017.568
Zhen, Y., Ning, Z., Shaopeng, Z., Yayi, D., Xuntong, Z., Jiachun, S., et al. (2015). A pH-and temperature-responsive magnetic composite adsorbent for targeted removal of nonylphenol. ACS Applied Materials \& Interfaces, 7, 24446-24457. https://doi.org/10.1021/acsami.5b08709

Zhu, H., \& Selim, H. M. (2000). Hysteretic behavior of metolachlor adsorption-desorption in soils. Soil Science, 165(8), 632-645. https://doi.org/10.1097/00010694-200008000-00005

Publisher's Note Springer Nature remains neutral with regard to jurisdictional claims in published maps and institutional affiliations. 